shrine, as a specific goal and objective ... the principle of editorial integrity, independent of any special interests." The statement should be reviewed by the JOC, and a formal process instituted to amend it as needed by the CMA board, the report states. As well, potential editors-in-chief and publishers must accept the statement before being hired.

The panel recommends that the CMA resume ownership of the publication is "in recognition of [CMAJ's] unique position" among other publications held by CMA Holdings.

The CMAH board's mandate focuses on business and financial considerations, the report notes, while the CMA's board has "a broader understanding of the importance of and contribution made by a medical journal to the entire community of readers."

As well, the current reporting structure "has resulted in a blurring of the lines of authority and accountability." As a result, the report states, the editorin-chief needs access to both the JOC and, if a dispute can't be resolved at that level, the CMA board of directors.

A revised and strengthened JOC, originally instituted in 2002, will play a large part in the restructured system. The JOC "if properly reconstituted and given adequate authority and deference" will provide the mechanism to resolve most potential disputes between the journal's owner, publisher and editor-in-chief and "minimize the likelihood of permanent damage to relationships between the parties," the report states.

The JOC will provide safeguards for the editor-in-chief, creating the criteria for performance review and ruling on any effort by the CMA to dismiss the editor without cause. As well, the 7-member JOC will now include a journalist.

The JOC itself will recommend who will sit on its committee, but the CMA Board of directors will make the final decision.

"Trust and good faith is a critical thing - they're right about that," Kassirer said. "So the spirit of the document is sound. It's the implementation that we'll have to wait and see."

Dr. Gordon Guyatt, a McMaster University researcher and long-time former contributor, said that while he is encouraged that the CMA accepted the report in full, it must embrace the spirit as well as the letter of the report.

Paul Knox, chair of Ryerson University's journalism school and a director of Canadian Journalists for Free Expression, said the new structure will provide a much better firewall between the editor and the owners. "I don't think it's completely fireproof, [but] it's better than the rather muddy structure that existed" during Hoey's tenure. - CMAJ

DOI:I0.1503/cmaj.060917

\section{Privatization key issue for}

\section{new CMA president}

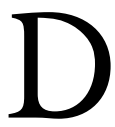
r. Colin McMillan can recall having lively debates with his father, "Dr. Joe," about the merits of medicare. Dr. Joe, a staunch opponent of government-funded health care, once squared off with David Lewis in a CBC TV debate in the '6os, and got involved with the CMA in hopes of stemming the dastardly tide. Yet ironically, son Colin, the CMA's new president, hopes to help craft a way to save medicare - albeit in modified form.

The Prince Edward Island cardiologist admires the CMA's "courage and

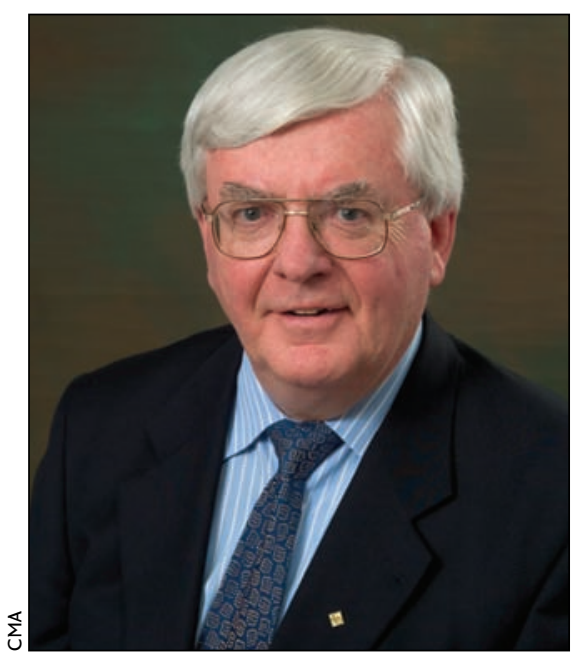

Prince Edward Island cardiologist

Dr. Colin McMillan leadership" in encouraging debate through its recent position paper (CMAJ 2006;175[I]:18-9). Like the CMA, McMillan supports the publicly funded health care system but "questions whether it is sustainable." He believes there's a need to have measurable outcomes and to put forward options that may include some privatization; a middle approach.

"It's no secret ... that [incoming president-elect Dr. Brian] Day will add another dimension to [the debate]," says McMillan. "I hope that doesn't polarize the issue or bring it around personalities."

Among other issues McMillan will face is the governance controversy at CMAJ. He supports editorial independence and autonomy for the journal: "We will do the best we can to ensure the elements people are looking for are well in place."

McMillan, $6_{3}$, is well prepared for these challenges. He's worked with the CMA since the early I 980 s as a member of the Political Action Committee, board of directors (1989-93) and chair of the board (1992-97). He will be installed as the I39th CMA President Aug. 23 at the conclusion of CMA General Council in Charlottetown.

Other focal points during his tenure will include health human resources, (including the possible development of a national authority to oversee HHR planning); leadership development among youth; and the adoption of information technologies. To that end, his office will be a pilot for introducing electronic records. McMillan will retain his practice throughout his tenure as CMA president, although he'll drop oncall duties at a local hospital.

The Rhodes Scholar, who earned his medical degree at McGill, is also a governor of the National Theatre School of Canada; a former director of the Heart and Stroke Research Foundation; and is active in several other charities. $\mathrm{He}$ and wife, Sandy, a realtor and local town councillor, have 5 children: twins Andrew and Alexandra (who is doing her residency in Ottawa), James, Victoria (deceased) and I6-year-old Virginia. - Barbara Sibbald, CMAJ

DOI:Io.I503/cmaj.060857 